\title{
Islamic Banking Products and Economic Development in Nigeria: A Co-Integration Approach
}

\author{
Habeeb Olaniyi Olayiwola \\ Federal Polytechnic, Ilaro, Nigeria
}

\begin{abstract}
Article History
Received: December,23 2021 Revised: December, 24 2021 Accepted: December, $24^{\text {th }} 2021$
\end{abstract}

\begin{abstract}
Corresponding

author:

E-mail:

habeeb.olayiwola@fe deralpolyillaro.edu.n g

The authorization of Taj Bank Limited to operate Islamic banking in Nigeria has reiterated the relevance of Islamic banking products and services in the nation's economy. However, the rate of patronage has been dampened compared to the conventional banks due to the issues of regulations and taxes, issues revolving around Sharia Scholars, Sharia-compliant products, and lack of awareness, among others. The study, therefore, investigates the nexus between Islamic banking products and economic development in Nigeria between 2013Q1 - 2019Q4. The data such as Human Development Index (HDI) proxy of economic development, and Islamic banking products; Murabahah (MUR), Wadiah (WAD), Istisna (IST), and Ijarah (IJA) were gathered from United Nations Statistics and Prudential and Structural Islamic Financial Indicators (PSIFIs). The data were analyzed using Eviews 9. The techniques adopted include descriptive statistics, correlation matrix, unit root test, co-integration statistics and Error Correction Model (ECM). The unit root test showed that all the data series were stationary at the first difference I(1). The co-integration results revealed the existence of a longrun relationship between Islamic banking products and economic development. However, the error correction model established that the short-run disequilibrium would be corrected and signed in the long run at $33 \%$. It was therefore concluded that there exists a nexus between Islamic banking products and economic development in Nigeria. The study recommends among others, that government should encourage more operations of Islamic banking so that Nigeria can achieve the objectives of financial inclusion, which is an essential ingredient of economic development.
\end{abstract}

Keywords: Co-integration, Economic Development, Islamic Banking, Sharia, Nigeria 


\section{Introduction}

Nigeria, as one of the largest economies in Africa, is characterized by multi-cultural, multiethnic and multi-religious groups. This has made the country to be a conglomerate and continued to witness significant changes and progress in Islamic banking (Mustafa \& Idris, 2015). Hence, the dominant activity of Islam as a complete system of life coupled with more emphasis on Islamic principles seems to be prosperous and immaculate, especially during the period of democratic dispensation in Nigeria.

Recently, the role of Islamic banking in an economy has grown substantially and creates a competitive environment and viable substitute for conventional banking due to its attribute of interest-free (riba or usury) and the underlining concepts of justice and risk-sharing (Benhayoun, Chairi, El-Gonnouni, \& Lyhyaoui, 2014). The system eliminates the concentration of wealth in the hand of a few individuals hence, bridging the gap between the rich and the poor (Ismail, 2010). Islamic banking takes the form of investment banks, commercial banks, insurance, investment and finance companies (El-Galfy \& Khiyar, 2012). However, it is based on different contracts which exclude borrowing and lending because interest is prohibited in Islamic law (Kahf, 2005).

Islamic financial institution has jurisdiction, as stated in the CBN Act that gave permission to such financial or banking practice, however, what is untrue is that the policy is meant to enforce Islam or Sharia on Nigerians (Nwaolisa \& Kasie, n.d). This issue can be confirmed by its operations with pros and cons that affect Muslims and non-Muslim alike, just like a conventional bank. The lending principle of Islamic banking is based on risk-sharing between the provider and the users of capital, and also, the depositors, the borrower and the bank share the reward and risk of financing the business ventures accordingly. Consequently, the demand for Islamic finances has been increasing as the population of Muslims, especially in African and Asian countries. It is estimated at 95\% of the world's Islamic population and predicted to rise by $35 \%$ or more in 2030 (PricewaterhouseCoopers, 2013).

Similarly, the recent statistics show that Islamic finance has spread across Africa, specifically in Nigeria, Gambia, Senegal, Sudan, Cote d'Ivoire, and Togo through their capital markets. In view of this, the Nigeria Stock Exchange (NSE) explains and emphasizes the benefits of investing in Islamic banking products and instruments to major investors. The potential growth of the Islamic financial model further necessitates the Nigerian government to organize several workshops to educate stakeholders on the potential growth of the instruments (Olawoyin, 2019). As part of the development, the CBN grants a licence to Taj Bank Limited on July 3, 2019, to operate Islamic banking business in the country. This bank and Jaiz Bank became the only two non-interest banks in Nigeria. Hence, Islamic banking products are generally developed to facilitate the economic and socio-economic development of the country.

Islamic finance has been proven to be a success in the United Arab Emirates and some countries in Africa, and its products and assets have been pinpointed as an engine of growth among policymakers (Olawoyin, 2019). As a result, businessmen or women (Muslim or 
non-Muslim) are expected to benefits from the services rendered by Islamic banking. Regrettably, the rate of patronage has been dampened compared to the conventional banks (Martin \& Osberge, 2013) due to the issues of regulations and taxes, the issues revolving around Sharia Scholars, Sharia-compliant products, lack of awareness, level of education and knowledge about Islamic banking coupled with the readiness of people to patronize lending facilities or being skeptical about Islamic banking products.

The stated challenges do not sway by the economic arguments on the activities of Islamic banking. Thus, some empirical studies were carried out to assess the influence of Islamic banking on the economy, but most of the results are inconclusive. Some literature has established a significant influence of Islamic banking on the growth of an economy (Adeel, Tariq, Ahmad, Ahmad, \& Shafique, 2015; Ledhem \& Mekidiche, 2020; Mustafa, Baita \& Usman, 2018; Lawal \& Imam, 2016; and Mustafa \& Idris, 2015), while others found the results to be otherwise (Furqani, \& Mulyany, 2009). These inconsistent results necessitate the renewed interest in the nexus between Islamic banking and economic development in Nigeria. Furthermore, most of the studies in Nigeria captured aggregate Islamic banking products and services and strictly focused on economic growth, hence the research gap to be filled. Thus, the study intends to examine the nexus between Islamic banking products and economic development in Nigeria.

\section{Literature Review}

\subsection{Islamic Finance and Economic Development}

In a broad sense, Islamic finance is centered on the foundation and principles put forward by the Islamic law (Sharia), which was captured in the Holy Quran (Islamic holy book) and the "Sunnah", practices and sayings of Prophet Mohammed (SAW) coupled with moral guidance or set of rules practiced by Muslims, and the Sharia Supervisory Board (SSB). Islamic banking is built on certain activities that forbid interest (riba). The term may refer to Riba-Al-Quran, or Riba-Al-Nasi'ah, which implies 'excess resulting from a pre-determined interest or interest charged on money lent.' It can also be Riba al-Hadith and Riba al-Fadl, which means 'excess benefits without consideration.' Other prohibited activities include prevention of deceit or uncertainty (Gharar), which may likely be in the form of short selling or fraud, and Maysir, known as Gambling, the likely involvement in speculative activities and gambling transactions (Olawoyin, 2019).

Shariah law is seen as a proactive item of protecting property rights in order to provide a solid form of banking operations, regardless of the country's legal system (Imam, 2010). Moreover, Islamic banks adhere to both Sharia and man-made laws, which conventional banks also operate, signifying its importance on economic growth. Today, Islamic banking is accepted in Western World due to occurring evils in society, including the evil effect on production, distribution, resources allocation, and expansion of artificial money and inflation (Saleem, 2008). Hassan and Dridi (2010) posit that the Islamic banking system ensures economic stability and growth in accordance with Sharia compliance and promotes entrepreneurs based on profit and loss sharing. 
There are various Islamic banking instruments and products traded in the Nigerian money and capital markets. These include Musharaka, Murabaha, Ijarah, Mudaraba, and Istisna'a, among others (Olawoyin, 2019; Lawal \& Imam, 2016). The Murabahah (cost-plus financing) is the structure of Islamic financing where a seller provides the cost and profit margin of an asset, i.e., non-interest-bearing loan (also called "qardh ribawi"), which is acceptable for credit sale under Islamic law.

Musharaka (Partnership) entails the involvement of all partners in profit sharing resulting from projects in a mutually agreed sharing ratio. Mudaraba, on the other hand, is a method of trust financing which allows one partner to provide investment (rab-ul-maal) and the other to invest in it (mudarib). Ijarah is an exchange transaction where the benefit emanates from a specific asset prepared for the use of clients in return for payment. Generally, Ijarah entails a contract in which Islamic financial institutions engage in financing/purchasing equipment, building or other facilities on behalf of its customer with the hope of recouping the principal sum coupled with some profits initially envisaged by both parties.

Istisna ' $a$ is a transaction that deals with deferred delivery and is applied to designed madeto-order items. It also involves a different form of sale where goods are transacted prior to their existence. However, it is essential to agree on a fixed price by both parties coupled with the specification required by the customer. Hence, the type of sale used as a mode of financing in this contract is called 'Parallel Istisna 'a'. Sukuk is the most famous instrument in Islamic finance in Nigeria, and it is prepared for the investors and other stakeholders influenced by the increasing and continuing interest in Islamic finance.

Economic Development, on the other hand, is often used interchangeably with economic growth, whereas development is wider in scope than growth. While economic growth is the increase in the output produced by a country over some time, Development is the creation of freedom for people and removal of obstacles to greater freedom (Sen, 2001). This implies that growth is just an important condition for development. Several economists have argued that development is about outcomes, and it arises when an economy witnesses poverty reduction, low unemployment and inequality. The objectives of development, as suggested by Dudley (1969), including an increase in living standards and individual self-esteem, expanding social and economic choice as well as minimizing fear, and producing 'life sustaining' necessities such as food, health and shelter. Overall, the United Nations developed acceptable indices of measuring development across countries, including the Human Development Index (HDI), and Human Poverty Index (HPI) (Saleem, 2008)

The Sharia, which is believed to offer remedies to social and economic problems, necessitates the need for Islamic financial institutions. This call has greater appeal in many countries, especially the Muslim countries, due to increased levels of unemployment, poverty and inequality. Some scholars argued that Islamic activities support a mentality and value system coupled with the attributes of individual responsibility and better performance, efficiency and effectiveness, or material wellbeing (Nienhaus, 1986). And this has been considered as a catalyst to better economic performance. While some refer to Islamic economics and finance as a very similar system to the social and economic system, others classify Islamic banking as a universal banking system (Saleem, 2008). It allows 
holding of equity and carrying out other operations such as insurance and trading, which often lie above the activity of the commercial bank. All these are prerequisites to economic growth and development (Zubair, 1995).

\subsection{Theoretical Review}

This study relies on the Solow growth model. The theory is an exogenous model of economic growth that discusses changes in economic output over a given period due to the population growth rate, saving and technological progress. The implication of the model is that there is no growth in the long run. Countries with diverse saving rates may likely have distinct steady states. Accordingly, a different saving rate will result in minimal growth in a country with lower capital stock. The theory assumed that the firm should produce maximum output using similar production technology that takes in inputs such as labour and capital. Thus, output level denoted by Y, capital as K, technology (A) and labour (L) are all related through the production function of $\mathrm{Y}=\mathrm{f}(\mathrm{K}, \mathrm{AL})$.

\subsection{Empirical Review}

The relationship between Islamic finance and economic growth has been proved in some economic literature. For instance, Muhammad and Dauda (2018) evaluated the effect of Islamic finance on economic growth in Nigeria covering the period between 2012 and 2015. The study found a positive and significant nexus between Islamic finance and economic growth. Tawfiqi, Hamdan, Masfaka and Muwafak (2018) assessed the role of Islamic banks in entrepreneurial success considering data sourced from 104 entrepreneurs in the Kingdom of Bahrain. It was concluded that Islamic banks play a significant role in the success of entrepreneurs in Bahrain. Adeel, Tariq, Ahmad, Ahmad and Shafique (2015) also examine the effectiveness of the Islamic banking system on economic development in Pakistan. Six interviews were conducted, and positive feedback was gathered. It was therefore discovered that Islamic banking contributes immensely to the growth of Pakistan's economy.

Abdu, Jibir, Abdullahi, and Rabiu (2018) investigated the impact of Islamic banking and financial inclusion in sub-Saharan Africa. The study established that Islamic finance in some Organization of Islamic Cooperation (OIC) countries in SSA contribute significantly to financial inclusion in the sub-region. It was further revealed that households from OIC with Islamic finance are observed to be involved financially compared to their counterparts without Islamic finance. Zulkhibri (2016) assessed the nexus between Islamic finance and financial inclusion using data obtained from various sources of Muslim countries' financial firms. It was revealed that in spite of the development of Islamic finance recently, many individuals are still financially excluded. Contrarily, Usman and Tasmin (2016) confirmed that Islamic finance had contributed significantly to financial inclusion through enhanced financial services and windows as well as human empowerment.

\section{Methodology}

The study employed both quantitative and qualitative research designs. The latter method is employed to review the existing literature from all relevant sources such as journals, magazines and textbooks. The former technique is used to examine the nexus between 
Islamic finance and economic development in Nigeria. The data were culled from the United Nations Statistics and Prudential and Structural Islamic Financial Indicators (PSIFIs) for Islamic Banks. More so, quarterly time series data covering the period of 2013Q1 - 2019Q4 was used. This is because the data relating to Islamic banking in Nigeria are limited, considering the system was introduced and implemented in 2012. The study considered data such as Human Development Index (HDI) and Islamic banking contracts, including Murabahah (MUR), Wadiah (WAD), Istisna (IST), and Ijarah (IJA).

\subsection{Model Specification}

The Solow Growth Model was adopted as a basis for the study where;

$\mathrm{Y}=\mathrm{F}(\mathrm{K}, \mathrm{AL})$

Y here denotes gross domestic product, $\mathrm{L}$ is labour, A represents technology, and $\mathrm{K}$ is capital.

$\mathrm{Y}$ is substituted for Human Development Index, $\mathrm{K}$ for Murabahah (MUR), L for Wadiah (WAD), A for Istisna (IST) and another variable like Ijarah (IJA) was included. Thus, the model is specified as follow;

HDI = f(MUR, WAD, IST, IJA, )

In explicit form

$\mathrm{HDI}=\beta_{0}+\beta_{1} \mathrm{MUR}+\beta_{2} \mathrm{WAD}+\beta_{3} \mathrm{IST}+\beta_{4} \mathrm{IJA}+\mu$

The explanatory variable in the model is therefore transformed into logarithms because of the nature of HDI data

$\mathrm{HDI}=\beta_{0}+\beta_{1} \ln M U R+\beta_{2} \ln W A D+\beta_{3} \ln I S T+\beta_{4} \ln I J A+\mu$

\subsection{Techniques of Estimation}

Descriptive Statistics: This statistic presents the characteristics of the variables used in the analysis. It takes cognizance of the sample means, the median, minimum, maximum, standard deviation of the variables etc.

Unit Root Test: This is conducted to determine whether the variables are stationary or not, i.e., establishing the order of integration of variables. Variables may be stationary either at level I(0), the first difference I(1) or the second difference I(2).

Cointegration Test and Error Correction Model (ECM): Co-integration analysis is conducted to examine the long-run relationship among the variables. The statistics procedure emphasizes the rank of matrix $\beta_{1}, \beta_{2}, \beta_{3}, \beta_{4}$, and $\beta_{5}$ which determines the number of cointegrating vectors.

Error Correction Model (ECM) for co-integrated variables is explained as reflecting partial adjustment of the variable to the other. It may also arise because one variable forecasts another. The model is specified as: 
Islamic Banking Products and Economic Development in Nigeria: A Co-Integration Approach Habeeb Olaniyi Olayiwola Page: 169-179

$\Delta H D I=\beta_{0}+\sum_{t=1}^{p 1} \beta 1 \Delta H D I_{\mathrm{t}-1}+\sum_{t=1}^{p 2} \beta 2 \Delta \ln M U R_{\mathrm{t}-1}+\sum_{t=1}^{p 3} \beta 3 \Delta \ln W A D_{\mathrm{t}-1}+$ $\sum_{t=1}^{p 4} \beta 4 \Delta \ln I S T_{\mathrm{t}-1}+\sum_{t=1}^{p 5} \beta 5 \Delta \ln I J A_{\mathrm{t}-1}+\lambda \mathrm{ECM}_{\mathrm{t}-1}+\mu$

The E-view 9 software was employed to analyze the data considered for the study.

\section{Empirical Result and Findings}

Table 1. Descriptive Statistics

\begin{tabular}{cccccc}
\hline & HDI & LNMUR & LNWAD & LNIST & LNIJA \\
\hline Mean & 0.528250 & 16.29841 & 16.65388 & 13.55010 & 11780308 \\
Median & 0.526000 & 16.58348 & 16.81113 & 13.86934 & 14781075 \\
Maximum & 0.541000 & 17.55018 & 18.07611 & 14.76428 & 20564046 \\
Minimum & 0.517000 & 14.24236 & 14.60263 & 11.39165 & 890345.8 \\
Std. Dev. & 0.006552 & 0.957895 & 1.019031 & 0.987346 & 5987396. \\
Skewness & 0.282490 & -1.253431 & -0.900254 & -1.351914 & -0.748359 \\
Kurtosis & 2.182207 & 3.517255 & 2.938189 & 3.770885 & 2.234527 \\
\hline
\end{tabular}

Source: Author's Computation and Eviews.

Table 1 shows the attributes of the Human Development Index (HDI), Murabahah, Wadiah, Instinah and Ijarah. It was discovered from the results that the maximum values of Islamic banking contracts geared up drastically from their minimum values in 2019. The maximum value of Murabahah indicates 17.55018 compared to a minimum value of 14.24236; Wadiah is 18.07611 as against 14.60263; Istinah with 14.76428(11.39165); and Ijarah of $20564046(890345.8$ ) with the standard deviation of $0.957895,1.019031,0.987346$, and 5987396, respectively. This implies a high level of growth of Islamic banking instruments in Nigeria despite its infant stage. The statistics also reveal that the mean value of HDI exceeds its median, which implies that the value is positively skewed while that of Islamic banking contracts is negatively skewed.

Table 2. Correlation Matrix

\begin{tabular}{cccccc}
\hline & HDI & LNMUR & LNWAD & LNIST & LNIJA \\
\hline HDI & 1 & 0.860669 & 0.911817 & 0.758210 & 0.855896 \\
LNMUR & & 1 & 0.986085 & 0.958581 & 0.946435 \\
LNWAD & & & 1 & 0.931714 & 0.954383 \\
LNIST & & & & 1 & 0.886384 \\
LNIJA & & & & & \\
\hline
\end{tabular}

Source: Author's Computation and Eviews

From the matrix results in table 2 , it could be seen that a positive and high correlation exists between HDI and InMUR, InWAD, InINST and InIJA at 0.86, 0.91, 0.76, and 0.86, respectively. Similarly, the correlation between Islamic banking contracts such as $\ln M U R, \ln W A D, \ln I S T$, and InIJA are high and positively related with each other. 
Table 3. ADF Unit Root

\begin{tabular}{cccc}
\hline Variable & Order of Integration & t-statistic & p-value \\
\hline HDI & $1(1) @ 5 \%$ & -3.797390 & 0.0082 \\
LnMUR & $1(1) @ 5 \%$ & -5.442506 & 0.0003 \\
LnWAD & $1(1) @ 5 \%$ & -4.533660 & 0.0000 \\
LnIST & $1(1) @ 5 \%$ & -4.267930 & 0.0027 \\
LnIJA & $1(1) @ 10 \%$ & -4.171314 & 0.0706 \\
*Significance level: $5 \%$ and $10 \%$ & &
\end{tabular}

Source: Author's Computation and Eviews

Based on the results of the Augmented Dickey Fuller (ADF) test, the data series such as HDI, InMUR, InWAD, and $\ln I S T$ were stationary at the first difference I(1) considering $5 \%$ critical value while InIJA is stationary at first difference with $10 \%$ level of significance. This implies that the probability values of HDI, lnMUR, lnWAD, and InIST were less than 0.05 , while the p-value of lnIJA is less than 0.1. Thus, the outcome of the unit root test confirms the suitability of co-integration analysis.

\subsection{Co-integration Statistics}

Johansen co-integration statistics were used to determine the existence of long-run association among the variables considered in the study. The test considers a $5 \%$ level of significance to determine whether the null or alternative hypothesis is to be accepted.

Table 4. Trace Test

\begin{tabular}{ccccc}
\hline $\begin{array}{c}\text { Hypothesized } \\
\text { No. of CE(s) }\end{array}$ & Eigenvalue & Statistic & $\begin{array}{c}0.05 \\
\text { Critical Value }\end{array}$ & Prob.** $^{*}$ \\
\hline None & 0.754159 & 62.46336 & 69.81889 & 0.1676 \\
At most 1 & 0.363484 & 25.98356 & 47.85613 & 0.8898 \\
At most 2 & 0.321161 & 14.23818 & 29.79707 & 0.8270 \\
At most 3 & 0.147919 & 4.166526 & 15.49471 & 0.8896 \\
At most 4 & 0.000177 & 0.004611 & 3.841466 & 0.9449 \\
\hline
\end{tabular}

Source: Author's computation and Eviews

From the statistics, it could be deduced that the probability value of the variable in each row exceeded $5 \%$ or 0.05 critical value. This implies that long-run association does not exist among the variables as reported by trace test.

Table 5. Maximum Eigen Test

\begin{tabular}{ccccc}
\hline $\begin{array}{c}\text { Hypothesized } \\
\text { No. of CE(s) }\end{array}$ & Eigenvalue & $\begin{array}{c}\text { Max-Eigen } \\
\text { Statistic }\end{array}$ & $\begin{array}{c}0.05 \\
\text { Critical Value }\end{array}$ & Prob.** \\
\hline None ${ }^{*}$ & 0.754159 & 36.47980 & 33.87687 & 0.0239 \\
At most 1 & 0.363484 & 11.74538 & 27.58434 & 0.9424 \\
At most 2 & 0.321161 & 10.07165 & 21.13162 & 0.7379 \\
At most 3 & 0.147919 & 4.161916 & 14.26460 & 0.8419 \\
At most 4 & 0.000177 & 0.004611 & 3.841466 & 0.9449 \\
ECM(-1) & -0.330450 & 0.116272 & -2.842048 & 0.0098 \\
\hline
\end{tabular}

Source. Author's computation from Eview 9 
From table 5, the Maximum Eigen Test reported 1 cointegrating equation at a 5\% critical value. As shown in the first row, the probability value of 0.0239 was less than 0.05 $(0.0239<0.05)$. Thus, there is a long-run relationship among the variables considered in the study.

Hence, the Economists have explained that when variables are cointegrated, Error Correction Model (ECM) must be conducted to explain the short-run dynamics of the cointegrated variables towards their equilibrium values. The results of ECM indicate that the error term is negatively signed and significant at 5\%. This implies that $33 \%$ disequilibrium is corrected on a yearly basis by changes in the economy. If an unexpected shock presents, the long-run equilibrium will return easily back to its steady-state.

Table 6. Breusch-Godfrey Serial Correlation LM Test

\begin{tabular}{|c|c|c|c|}
\hline F-statistic & 2.240730 & Prob. F(2,19) & 0.1337 \\
\hline Obs*R-squared & 5.152977 & Prob. Chi-Square(2) & 0.0760 \\
\hline \multicolumn{4}{|c|}{ Heteroskedasticity Test: Breusch-Pagan-Godfrey } \\
\hline F-statistic & 0.556866 & Prob. F $(5,21)$ & 0.7316 \\
\hline Obs*R-squared & 3.160773 & Prob. Chi-Square(5) & 0.6752 \\
\hline Scaled explained SS & 1.837649 & Prob. Chi-Square(5) & 0.8711 \\
\hline
\end{tabular}

Source: Author's Computation from Eview 9

Table 6 shows the results of Breusch-Godfrey Serial Correlation LM and Heteroskedasticity tests. Based on the results, it was observed that autocorrelation does not exist among the variables since the p-value exceeds 0.05 (5\% critical value). Similarly, the chi-square probability value of 0.6752 , which is greater than a $5 \%$ significant level, confirmed the absence of heteroskedasticity among the variables of the study. Thus, the study concludes that the model is freed of any heteroskedasticity problem.

\section{Conclusion and Recommendations}

The findings of the unit root test indicate that all the data series are stationary at the first difference I(1), considering 5\% and 10\% levels of significance. The co-integration result revealed the existence of a long-run relationship between Islamic banking contracts and economic development. However, the error correction model established that the short-run disequilibrium would be corrected and signed in the long run at $33 \%$. Based on the findings, the study confirms the presence of a long-run association between Islamic banking and economic development in Nigeria despite its shortest period of implementation. It was therefore concluded that Islamic banking products/finances contributed immensely to the growth and development of the Nigerian economy. The study suggests, among others:

First, the government should educate the citizen on the benefits poses by Islamic banking services and products.

Second, a Sharia-compliant money market should be developed by the government. This will allow Islamic banks to manage effective liquidity in order to free resources and handle other growth-enhancing projects. 
Furthermore, the government should encourage more operations of Islamic banking so that Nigeria can achieve the objectives of financial inclusion, which is an essential ingredient of economic development.

\section{References}

Abdu, M., Jibir, A., Abdullahi, S., \& Rabiu, A. A. (2018). Can Islamic banking and finance spur financial inclusion? Evidence from sub Sahara Africa. CBN Journal of Applied Statistics, 9(1), 77-104.

Adeel, A., Tariq, A., Ahmad, N., Ahmad, H., \& Shafique, M. N. (2015). Does Islamic banking system contributes to economic development?. Arabian Journal of Business and Management Review, 3(8), 1-5.

Benhayoun, N., Chairi, I., El Gonnouni, A. \& Lyhyaoui, A. (2014). Islamic banking challenges lie in the growth of Islamic economy despite of the free interest loans policy: Evidences from Support Vector Machine Approach. ACRN Journal of Finance and Risk Perspectives, 3(1), 19 - 31

El-Galfy, A. \& Khiyar, K. A. (2012). Islamic banking and economic growth: A review. The Journal of Applied Business Research, 28 (5), 943-955

Furqani, H., \& Mulyany, R (2009). Islamic banking and economic growth: Empirical evidence from Malaysia. Journal of Economic Cooperation and Development 30(2), 59 -74.

Hassan, M, \& Dridi, J. (2010). Put to the test Islamic banks were more resilient than conventional banks during the global financial crisis. Finance and Development, 46-47.

Imam, J. S. (2010). MicroRNA-185 suppresses tumor growth and progression by targeting the Six1 oncogene in human cancers. Oncogene, 29(35), 49-71

Ismail, A. G. (2010). Islamic banks and wealth creation. ISRA Research Paper No 9/2010. International Shari'ah Research Academy for Islamic Finance

Kahf, M. (2005). Islamic Banking and Development: An Alternative Banking Concept? In Hassan and Lewis Handbook. 1-15.

Lawal, I. M., \& Imam, U. B. (2016). Islamic finance and economic growth: Empirical evidence from Nigeria. Journal of Economics and Sustainable Development, 7(16), 99-108

Ledhem, M. A., \& Mekidiche, M. (2020). Economic growth and financial performance of Islamic banks: A CAMELS approach. Islamic Economic Studies, 28(1), 47-62

Martin, R. L. \& Osberg, S. (2013). Social entrepreneurship: The case for definition-based enterprise. Academy of Management Review, 31 (2), 309-328

Muhammad, T. \& Dauda, S. (2018). Islamic finance in promoting economic growth in Nigeria. South East Asia Journal of Contemporary Business, Economics and Law, 15(5), 41- 45

Mustapha, D., Baita, A. J., \& Usman, A. Y. (2018). Impact analysis of Islamic finance on financial inclusion and economic growth in selected Muslim countries: Lessons for Nigeria. International Journal of Economics, Management and Accounting 26(2), 393414

Mustapha, D. A, \& Idris, M. (2015). The contributions of Islamic economics and institutions to modern Nigeria. Journal of Islam in Nigeria, 1(1), 36-58.

Nienhaus, V. (1986). Islamic economics, finance and banking, Journal of Economics, Banking and Finance, 3(1), 36-54

Nwaolisa, E. F. \& Kasie, E. G. (n.d). Islamic banking in Nigeria: A critical appraisal of its effect on the Nigerian economy, $37-48$

Olawoyin, 0. (2019). What Islamic finance products can do to Nigeria's capital market, infrastructural growth? Premium Times, August 13, 2019, 1-13.

PricewaterhouseCoopers (2013). Islamic finance: Creating value, 1-36. Available at www.pwc.com 
Islamic Banking Products and Economic Development in Nigeria: A Co-Integration Approach

Saleem, S. (2008). Role of Islamic banks in economic development. MPRA Paper No. 6449, 1-77.

Sen, A (2001). Development as freedom, (2 ${ }^{\text {nd }}$ edition). New York: Oxford University Press. ISBN 9780192893307

Tawfiqi, D. N., Ahlia, A. H., Masfaka, M. M., \& Muwafak, B. M. (2018). The role of Islamic banks in the entrepreneurial success: Evidence from Bahrain. International Journal of Entrepreneurship, 22(2), 1- 22

Usman, A. S., \& Tasmin, R. (2016). The role of Islamic microfinance in enhancing human development in Muslim countries. Journal of Islamic Finance, 5(1), 053-062.

Zubair, H. (1995). Economic Development in Islamic Perspective: Concept, Objectives, and Some Issues. Journal of Islamic Economics 1(6), 80-111.

Zulkhibir, M. (2016). Financial inclusion, financial inclusion policy and Islamic finance. Macroeconomics and Finance in Emerging Market Economies, 9(3), 1-18.

\section{Appendix}

\begin{tabular}{|l|l|l|l|l|l|}
\hline Year & HDI & Murabahah & Wadiah & Istisna & Ijarah \\
\hline $2013 Q 1$ & 0.517 & $1,532,426.1$ & $2,197,058.6$ & $88,579.2$ & $890,345.7$ \\
\hline $2013 Q 2$ & 0.518 & $1,532,426.1$ & $2,197,058.6$ & $88,579.2$ & $890,345.7$ \\
\hline $2013 Q 3$ & 0.52 & $1,532,426.1$ & $2,197,058.6$ & $88,579.2$ & $890,345.7$ \\
\hline $2013 Q 4$ & 0.521 & $1,532,426.1$ & $2,197,058.6$ & $88,579.2$ & $890,345.7$ \\
\hline $2014 Q 1$ & 0.522 & $6,601,811.9$ & $8,917,830.8$ & $361,249.0$ & $3,626,188.0$ \\
\hline $2014 Q 2$ & 0.523 & $7,115,349.3$ & $8,661,037.7$ & $609,035.0$ & $5,382,737.3$ \\
\hline $2014 Q 3$ & 0.523 & $9,214,093.5$ & $10,956,802.0$ & $637,116.1$ & $7,203,515.2$ \\
\hline $2014 Q 4$ & 0.524 & $11,767,138.5$ & $10,847,965.3$ & $722,676.1$ & $8,213,086.1$ \\
\hline $2015 Q 1$ & 0.525 & $12,164,235.8$ & $13,157,661.1$ & $805,100.9$ & $8,962,312.3$ \\
\hline $2015 Q 2$ & 0.526 & $10,957,483.1$ & $15,135,565.2$ & $856,170.2$ & $10,054,645.0$ \\
\hline $2015 Q 3$ & 0.526 & $11,417,711.2$ & $15,446,438.3$ & $1,020,413.1$ & $11,649,621.8$ \\
\hline $2015 Q 4$ & 0.526 & $11,792,435.1$ & $16,475,620.3$ & $781,891.3$ & $12,890,684.7$ \\
\hline $2016 Q 1$ & 0.525 & $12,998,469.4$ & $20,626,362.4$ & $1,138,788.9$ & $14,218,017.6$ \\
\hline $2016 Q 2$ & 0.526 & $15,218,536.4$ & $18,833,301.4$ & $1,032,372.0$ & $15,024,741.5$ \\
\hline $2016 Q 3$ & 0.526 & $16,666,982.2$ & $19,388,196.1$ & $1,265,839.0$ & $15,483,611.9$ \\
\hline $2016 Q 4$ & 0.527 & $18,579,712.3$ & $24,415,544.1$ & $1,099,753.4$ & $16,495,379.2$ \\
\hline $2017 Q 1$ & 0.529 & $18,444,622.9$ & $31,292,851.0$ & $1,084,663.3$ & $15,921,514.8$ \\
\hline $2017 Q 2$ & 0.531 & $20,294,979.1$ & $31,046,130.4$ & $1,078,752.8$ & $16,662,156.8$ \\
\hline $2017 Q 3$ & 0.532 & $19,358,293.2$ & $25,639,376.7$ & $994,233.2$ & $16,417,685.2$ \\
\hline $2017 Q 4$ & 0.532 & $24,718,261.7$ & $33,706,359.0$ & $1,599,124.4$ & $15,625,192.7$ \\
\hline $2018 Q 1$ & 0.533 & $22,407,123.8$ & $34,709,800.0$ & $1,590,030.3$ & $15,381,975.5$ \\
\hline $2018 Q 2$ & 0.533 & $23,426,775.7$ & $39,164,072.0$ & $2,549,891.6$ & $15,519,944.9$ \\
\hline $2018 Q 3$ & 0.534 & $24,606,044.5$ & $33,248,734.7$ & $2,582,519.1$ & $14,837,144.6$ \\
\hline $2018 Q 4$ & 0.536 & $26,466,797.3$ & $41,343,377.7$ & $1,988,377.2$ & $16,747,625.0$ \\
\hline $2019 Q 1$ & 0.537 & $23,816,932.3$ & $46,792,529.1$ & $1,484,296.0$ & $14,725,004.4$ \\
\hline $2019 Q 2$ & 0.538 & $26,821,469.2$ & $55,324,142.4$ & $1,296,797.3$ & $16,344,093.4$ \\
\hline $2019 Q 3$ & 0.54 & $30,810,980.1$ & $57,095,422.6$ & $1,260,387.1$ & $18,336,319.0$ \\
\hline $2019 Q 4$ & 0.541 & $41,874,093.9$ & $70,852,833.7$ & $1,123,004.1$ & $20,564,045.9$ \\
\hline
\end{tabular}

Source: United Nations Statistics and Prudential and Structural Islamic Financial Indicators (PSIFIs) 